\title{
How do intergovernmental organizations embed themselves in global value chains: A case study of Gavi
}

\author{
Melodena Stephens, Immanuel Azaad Moonesar
}

\begin{abstract}
A B S T R A C T
Objective: The article's objective is to understand how non-MNE actors in the global arena, like intergovernmental organizations (IGOs) embed themselves in the global value chain by using their strong ties to states.

Research Design \& Methods: For this study, a qualitative methodology approach investigates an underexplored area of research using a single case study, GAVI, that utilizes thick data.

Findings: The paper contributes to our understanding of IGOs and how they internationalize. New motives are identified, and the concept of soft power has been extended to IGOs.

Implications \& Recommendations: IGOs in the humanitarian or developmental sector use soft power strategies to embed themselves in the global value chain. The paper's implications are for policymakers and practitioners in the third sector, including those who invested interest at state-represented foreign direct investment. Future studies can look at how networks are leveraged, spillover occurs from a personal level to an institutional level, and vice-versa combining diplomacy, bargaining, and legitimacy.
\end{abstract}

Contribution \& Value Added: The study highlights new areas of research like that of soft power. The current internationalization models of SMEs and MNEs may not neatly fit in the context of IGOs (which are born global). We reiterate that existing IB theories need to be applied to other state actors like sovereign wealth funds and non-governmental organizations. The above case study, a detailed historical analysis using thick data, is a methodology not often published.

$\begin{array}{ll}\text { Article type: } & \text { research article } \\ \text { Keywords: } & \text { Global value chain, soft power, legitimacy, strategic seeking FDI, GAVI, Global factory } \\ \text { JEL codes: } & \text { E22; F21; F01 }\end{array}$

Received: 17 March $2021 \quad$ Revised: 3 June $2021 \quad$ Accepted: 13 June 2021

\section{Suggested citation:}

Stephens, M., \& Moonesar, I.A. (2021). How do intergovernmental organizations embed themselves in global value chains: A case study of Gavi. International Entrepreneurship Review, 7(3), 7-21. https://doi.org/10.15678/IER.2021.0703.01

\section{INTRODUCTION}

The 'global factory' is a concept introduced by Peter Buckley (Buckley, 2004). He argues that globalization has led to multinational enterprises (MNEs) using the global arena to distribute their business in such a way to ensure maximum profits (Buckley,2009a). While much of international business (IB) using the concept of global value chains in regards to the private sector, nations, and non-profits also use this concept. The earliest example is the Dutch East India Company (VOC), founded in 1602, and the English East India Company (EIC), founded in 1600. These organizations moved from private initiatives to institutional state-funded organizations, to later Company-State (Weststeijin, 2014), with VOC being the first to be listed on a stock market. Other state-funded global firms are state-owned enterprises (SOEs) or sovereign wealth funds (SWFs).

However, intergovernmental organizations (IGOs) are a neglected category in IB literature (Milner, 1999) and often clubbed with non-government organizations, which may not all be international. The number of institutions of 7658influence foreign direct investment (FDI) (Union of International Associations [UIA], 2018) or trade (Ingram et al., 2005). Research finds that IGOs impact member countries 
more than non-member countries (at least in trade) through a relationship of direct exercise of organizational and bureaucratic control, often through NGOs and MNCs (Ingram et al., 2005). This research categoryfalls into the area of an "institutional abyss," with most studies focusing on the World Trade Organisation and International Monetary Fund (Alacer \& Ingram, 2013, p. 1056). IGOs tend to signal relational governance and overcome trade distance through transactional costs (Alcacer \& Ingram, 2013; Ingram et al., 2005). Suddaby (2010) finds part of the challenge is that institutional theory may not be enough to explain how NGOs operate. The theory needs to be refocused "to explore more fully the interpretive capacities of organizations and consider closely the possibility that organizations are much more sophisticated managers of symbolic resources than organizational theory presently admits to" (p. 18).

IGOs are an outcome of economic and political factors globally and nationally (Lee, 2010). Teegen et al. (2004) highlight the importance of non-governmental organizations (making no distinction between them and IGOs) in value creation and governance from the lens of institutional theory and the bargaining model. However, they state there are similarities with MNEs, especially if you look at the purpose as "value creation and distribution," where profits are just one outcome (Teegen et al., 2004, p. 476). The value IGOs create maybe debatable. Moore et al. (2019), in their study of IGOs, looked at 272 country-year panel observations across 68 countries from 2000 to 2011 and found that IGOs promote formal entrepreneurship but hindered informal entrepreneurship in the least developed countries, irrespective of the type of IGO (social, political, or economic). Shenkar (2004) and Teegen et al. (2004) call for more research in this area and encourage a revisit of theories like that of ownership, location, and internalization factors (OLI) (Dunning 1988, 2001), to see its relevance in international business, primarily as they operate as multinationals.

IGOs are global by membership. IGOs strongly influence member state economic policies, including FDI and knowledge flows (Jandhyala, \& Phene, 2015). Contrary to the perceptions that IGOs are neutral, there is the field of thought that IGOs are vehicles of states used to mold the global system (Mearsheimer, 1995). This was reinforced in the study of IGOs working for peace, where the authors concluded, "The contribution of IGOs to peace depends not so much on forging common bonds or on converting international anarchy as it does on creating conditions that encourage effective interstate bargaining" (Boehmer et al. 2004, p. 28). This paper aims to understand how other influential actors in the global arena like IGOs embed themselves in the global value chain to using their strong ties to states (Moore et al., 2019). The paper will look at existing theories on motives, strategic seeking FDI, legitimacy, and soft power concerning how IGOs embed themselves in the global value chain. Soft power is a relatively unexplored concept in IB literature.

The paper's structure is as follows: first, we will recap the current research on IGOs. This will be followed by a brief introduction to the literature on strategic asset-seeking FDI, networking, soft power, and legitimacy, areas that IGO literature does not fully explore from a global supply chain perspective. Then the methodology will be discussed, and the case analyzed. Using thick data (qualitative/ case-rich), we will open a "black box" of how and why IGOs internationalize (Doz, 2011). Finally, a conceptual model will be presented, followed by a brief discussion.

\section{LITERATURE REVIEW}

\section{Internationalizations of IGOs}

IGO are entities created by treaty, involving two or more nation-states to work in good faith, on issues of common interest, and subject to international law. Often, they consist of memberships of states.IGOs are significant actors in the diplomatic arena, providing ties that more formal diplomatic missions may not be able to create (Vabulas \& Snidal, 2013). IGOs are embedded into the global value chain. The development of strategic location bases is often attributed to IGO-IGO linkages (Ingram et al., 2005).It is estimated that trade between countries increases by $58 \%$, doubling the strength of IGO connections between the nations, and increasing economic effect for social/cultural IGOs to $24 \%$ to $80 \%$ (Alacer \& Ingram, 2013; Ingram et al. 2005). This may appear to be preconditioned by the salience of the field of activity of the IGO, or the degree of similarity between two actors (Lorrain \& White, 1971). 


\section{Motives of IGOs}

Some work on IGOs and motives exists depending on purpose, membership, or logic of behavior (see Table 1).

Table 1. Motives of IGOs

\begin{tabular}{|l|l|c|}
\hline \multicolumn{1}{|c|}{ Classification } & \multicolumn{1}{|c|}{ Categories } & \multicolumn{1}{c|}{ Author } \\
\hline Purpose & (1) general-purpose (2) military, (3) economic or (4) social/cultural. & Jackson (2006) \\
\hline Membership & $\begin{array}{l}\text { (1) universal - allows membership from all nations like the UN } \\
\text { (2) international, across countries and continents like ASEAN } \\
\text { (3) regional, across countries in the same continent like EU and } \\
\text { (4) purpose defined (single purpose or multi-purpose), can be selective } \\
\text { in membership, like NATO and OPEC. }\end{array}$ & Hough et al. (2010) \\
\hline Logic of behaviour & $\begin{array}{l}\text { (1) Functional IGOs focussing on pragmatic legitimacy (immediate tar- } \\
\text { get audience's self-interest - donor states). } \\
\text { (2) Normative IGOs focus on moral legitimacy (broader societal welfare } \\
\text { of the community over donors). }\end{array}$ & Suchman (1995) \\
\hline
\end{tabular}

Source: own study.

In terms of purpose, IGOs maybe exclusive. The fact that many more prosperous states belong to IGOs (e.g., Beckfield, 2003) maybe in line with the Demographic-Structural theory that highlights the oversupply of elites (and elites' aspirants), leading to the creation of vehicles for the maintenance of status and wealth (Goldstone, 1991; Turchin \& Nefedov, 2009). Membership is restricted to ensure compliance with institutional rules (Koremenos et al., 2001). This may lead to a perception that IGOs may act like cartels and control the prices of world commodities (Haynes et al., 2017). Surprisingly little research exists in the field of IGOs in the arena of international business, though they influence nonmember states and can benefit member states.

In IB literature, strategic asset-seeking FDI is crucial for internationalization tocreate or gain access to resources and capabilities complementing the existing core competencies (Dunning, 1993; Dunning \& Lundan, 2008). It is used as a strategy to manage assets and resources via (1) leveraging or augmenting existing assets (e.g., Meyer et al., 2009; Narula, 2006; Narula\& Dunning, 2000;Narula \& Zanfei, 2004);or asset exploration (Meyer, 2015) or accumulating new strategic assets (e.g., Narula, 2006).This maybe upstream or downstream (Pananond, 2015), which gives a strategic competitive advantage. But the challenge in applying this concept to IGOs is highlighted by the central premise of strategic seeking FDI. Dunning believes that "a firm's ability to benefit from such activities must be related to the assets which it possesses before the act of internalization" (Dunning, 2001, p. 175), which limits its application to IGOs as they are not investing in either horizontal or vertical FDI in the conventional meaning of the terms, as they do not create subsidiaries and often do not exploit markets in the terms with which we refer to MNEs. In one of the few studies that exist, an IGO contributed to local, national innovation by leveraging external knowledge (Jandhayala \& Phene, 2015). Hence this is an area for further research.

\section{Networks: Sources of Legitimacy and Soft Power}

The global factory presupposes global differentiated networks (Buckley 2009a, 2009b). In these networks, the state often becomes an active partner (Gereffi \& Korzeniewicz, 1994). It will lobby for trade, help build capabilities, give access to resources, or protect at an incentivized rate, making the organization more competitive in the global marketplace. Many well-known IGOs are strategically based in Washington, New York, Geneva, or Brussels, so location matters. However, they do not directly get involved in manufacturing but can facilitate it. Since they can attract enormous resources and reallocate them - this is significant. For example, the three largest IGOs are the United Nations (UN), the World Trade Organization (WTO), and the North Atlantic Treaty Organization (NATO) (See Table 2). IMF, which has its $\mathrm{HQ}$ in Washington, and 189 members, gives loans at reduced interest rates to member countries and for 2018 had a budget of US dollars 1,104 million (majority for personnel) and gave US dollars 91 billion to four countries and US dollars 2.4 billion to low-income countries (IMF, 
2018).World Bank has 189 member countries, and in the financial year, 2017-18 committed US Dollar 67 billion in financing, investments, and guarantees. WB works through other organizations like The International Bank for Reconstruction and Development (IBRD) and the International Development Association (IDA). There is little research available on the global networks of IGOs - donors, affiliated organizations, or locational choices that affect how they impact, influence, or do international business of money management, investments, human resources management, or its impact on GDP.

Table 2. Funding of the Three Largest IGOs and IMF and WB since its inception

\begin{tabular}{|l|l|l|l|l|l|}
\hline Organisation & Creation & Members & $\mathbf{2 0 1 8}$ Budget (€ million) & Mission & Headquarters \\
\hline UN & 1945 & 193 & 2295 & Peace \& Security & New York \\
\hline WTO & 1995 & 164 & 173.5 & Trade & Geneva \\
\hline NATO & 1949 & 29 & 1546.5 & Defence & Brussels \\
\hline
\end{tabular}

Source: European Parliament (2020).

In the country-of-origin studies in IB, we see the impact of the country's reputation; however, for IGOs, legitimacy is more critical(Deephouse \& Carter, 2005) as it is considered a capital asset of the state (Gallarotti, 1989). Buckley (2009a) mentions that the global factory strategy is designed to achieve global legitimacy but does not give details on the process discussed above. IGOs have to achieve legitimacy as an entity, and they gain legitimacy from their donor countries, which gives them influence in markets that they work in or with. As in WB or IMF, the recipient countries are at a lower economic status than funding countries. In some cases like NATO, funding members will take decisions that will also impact countries not aligned to their interests. This concept is in line with the quality of hard power - the ability to coerce another country to do what is in its interest.

Most IGOs work with soft power - the ability to influence other courtiers to do what is in their interest (Nye 1990, 2009), which is tied to legitimacy (Nye, 2008). This concept of soft power is relatively new in IB theory. GOs are exposed to (1) their domestic political arena, (2) the national political arenas of recipient economies, and (3) the international public policy arena-making (Behrendt, 2009). In addition, (4) the third sector political arena and (5) the impact policy arena. There is a need to focus on building legitimacy as an asset through the role of soft power.

In conclusion, the literature on the internationalization of IGOs is scarce. Therefore, there is a need to understand how motives like strategic seeking FDI with few case examples are needed.

\section{RESEARCH METHODOLOGY}

A qualitative methodology to work in an underexplored area of research (Birkinshaw et al., 2011) using a single case study (Bourdieu 1990; and Grant, 2003).The case study is Gavi, the Global Alliance for Vaccines and Immunization, a Switzerland-based IGO, was chosen for analysis. The case had access to thick data and a history of global expansion (Eisenhardt \& Graebner, 2007; Yin, 1994). The detailed case data came from a historical analysis (see Stephens Balakrishnan \& Moonesar, 2011; Stephens Balakrishnan, 2016). Gavi, the Vaccine Alliance, was documented from 1998-2018 through interviews and secondary research (See Table 3).

\section{Research Methods}

The process used for analysis is a meta-synthesis, which is defined as an "exploratory, inductive research design to synthesize primary qualitative case studies to make contributions beyond those achieved in the original studies" (Hoon, 2013, p. 523). The data analysis units are (1) motives and (2) networks for legitimacy and soft power. These were cross-referenced with the theoretical perspectives highlighted above. The original case was written using multiple perspectives, triangulated with secondary data, and the sequence and context verified internally for fact-checking. Since the phenomena are dynamic, the cases were updated using secondary research (Corbin \& Strauss, 2008). The case was then individually analyzed using the theoretical paradigms, then compared against each other for similarity and differences (Corbin \& Strauss, 2008). Below is a brief description of the case, looking at 
origins, locations, market, resources, arena, employees, focus areas, competencies, rent, industry, growth, and governance (Table 4). The membership is representative yet selective. Finally, the overarching theoretical framework is presented.

Table 3. Data Sources for Case Analysis: Gavi (2000-2020)

\begin{tabular}{|l|l|}
\hline \multicolumn{1}{|c|}{ Analysis } & \multicolumn{1}{c|}{ Gavi, the Vaccine Alliance } \\
\hline $\begin{array}{l}\text { Secondary Sources referenced (not including } \\
\text { those that were reviewed but not used in the } \\
\text { development of the case) }\end{array}$ & $\begin{array}{l}141 \text { secondary sources (articles, the internal document, annual re- } \\
\text { views, partner reviews) and multiple websites of alliance mem- } \\
\text { bers. }\end{array}$ \\
\hline $\begin{array}{l}\text { Interviews and data verification contacts } \\
\text { (function \& level) }\end{array}$ & $\begin{array}{l}\text { Interviews and data verification (Senior Manager, Resource Mobi- } \\
\text { lization \& Private Sector Partnerships; Analysts (monitoring \&con- } \\
\text { sultation); \&Communication team; expert in Epidemiology, Infec- } \\
\text { tious Diseases and Oncology working with INFUSE; Head, Strategic } \\
\text { Innovation - Resource Mobilization, Private Sector Partnerships, } \\
\text { \& INFUSE, and Gavi's external consultant). }\end{array}$ \\
\hline Published Cases & $\begin{array}{l}\text { Gavi, the Vaccine Alliance: Saving Lives One Vaccine at a Time (53 } \\
\text { pages) + Gavi, the Vaccine Alliance: reshaping the vaccine market } \\
\text { (7 pages). }\end{array}$ \\
\hline
\end{tabular}

Source: own study.

Table 4. A brief synopsis of Gavi, the Vaccine Alliance $2000-2018^{1}$

\begin{tabular}{|c|c|}
\hline Facts & Gavi, The Vaccine Alliance \\
\hline Origins & USA: Initiative by the Bill \& Melinda Gates Foundation (BMGF). \\
\hline Employees & $450+$ \\
\hline Locations & $\begin{array}{l}\text { Headquarters: Geneva Switzerland, with an officeinWashington DC; Innovative finance admin- } \\
\text { istered by World Bank (USA) through IFFIm (UK). Anchor Founding member is BMGF (USA). } \\
\text { R\&D: dynamic - based on need and qualified applicants. } \\
\text { Locations - coordination in the group with partners and through their offices across all Gavi } \\
\text { eligible countries. } \\
\text { Markets of Manufacturing: } 5 \text { vaccine manufacturers in 2001; by 2017, } 17 \text { vaccine manufactur- } \\
\text { ers of which } 11 \text { are based in Africa, Asia, and Latin America. [Based on tenders administered by } \\
\text { UNICEF (Switzerland), pre-qualified by World Health Organisation (WHO) (Switzerland)] }\end{array}$ \\
\hline Market & $\begin{array}{l}\text { Global Markets of Impact as of 2017: direct impact: over } 690 \text { million children vaccinated and } \\
\text { over } 10 \text { million deaths averted. Countries of impact: } 77 \text { countries carry out nearly } 400 \text { vaccine } \\
\text { introductions and campaigns at the end of } 2017 \text {, prices of vaccines reduced. }\end{array}$ \\
\hline Resources & $\begin{array}{l}\text { Markets of Funding as of } 2017 \text { : Two funding streams- direct contributions (76\%) and innova- } \\
\text { tive finance (24\%), funding more than } 90 \text { million vaccine doses through global stockpiles at the } \\
\text { end of } 2017 \\
\text { European Commission and } 21 \text { donor governments:Australia, Canada, China, France, Germany, } \\
\text { Ireland, Italy, Japan, the Kingdom of Saudi Arabia, Luxembourg, the Netherlands, Norway, the } \\
\text { Principality of Monaco, the Republic of Korea, the State of Qatar, the Sultanate of Oman, } \\
\text { Spain, South Africa, Sweden, the United Kingdom and the United States of America. Contribu- } \\
\text { tions from India, the Republic of Korea, and the United Arab Emirates were renewed during } \\
\text { the year. } \\
\text { Foundations, organizations: Alwaleed Philanthropies, Bill \& Melinda Gates Foundation, His } \\
\text { Highness Sheikh Mohammed bin Zayed Al Nahyan, OPEC Fund for International Development } \\
\text { (OFID), Absolute Return for Kids, Anglo American plc, The Children's Investment Fund Founda- } \\
\text { tion (UK), China Merchants Group, Comic Relief, ELMA Vaccines, and Immunization Founda- } \\
\text { tion, Girl Effect, International Federation of Pharmaceutical Wholesalers (IFPW), Gulf Youth } \\
\text { Alliance, "Ia Caixa" Foundation, LDS Charities, Lions Clubs International Foundation (LCIF) } \\
\text { Corporations: Deutsche Post DHL, JP Morgan, Majid AI Futtaim, Orange, Philips, Unilever, UPS, } \\
\text { Vodafone } \\
\text { Gavi works with Bill \& Melinda Gates Foundation, International Finance Facility for Immuniza- } \\
\text { tion (IFFIm), UNICEF, WHO, Pfizer, GSK, Merck,AMC, PAHO, World Bank, civil societyorganiza- } \\
\text { tions. There are } 60 \text { partners in the partners' engagement framework. }\end{array}$ \\
\hline
\end{tabular}

\footnotetext{
${ }^{1}$ The Gavi Alliance by the World Bank Group. Retrieved from: https://documents1.worldbank.org/curated/zh/9288714681
} 97087690/pdf/The-World-Bank-s-partnership-with-the-GAVI-alliance.pdf 


\begin{tabular}{|c|c|}
\hline Rent & $\begin{array}{l}\text { Total Funding from 2000-2017: USD } 15.4 \text { billion } \\
\text { Through legitimacy, Gavi is able to acquire innovative financing ( } 24 \%) \text { : } \\
\text { (1) Advanced Market Commitment (AMC) - USD } 1.5 \text { billion [Governments of Italy, UK, Can- } \\
\text { ada, Russian Federation \&Norway and B\&MGF] } \\
\text { (2) Matching Fund - USD } 87 \text { (Includes INFUSE which is supported by the Governments of } \\
\text { Canada and the United Arab Emirates with USD } 21 \text { million) } \\
\text { (3) Vaccine Bonds/Social Bonds (IFFIm) - since } 2006 \text {, using USD } 6.5 \text { billion in sovereign } \\
\text { pledges and to front-load vaccine delivery to the tune of USD } 2.6 \text { billion. Loan buydown for } \\
\text { Sahel region with Gavi, the Bill \& Melinda Gates Foundation and the French Development } \\
\text { Agency- since } 2016, \text { pooled } € 100 \text { million. } \\
\text { In addition, to direct funding \& contributions (76\%). Advocacy helps get vaccines on the agenda. } \\
\text { Impact: USD100 billion in terms of economic benefit of vaccinations. }\end{array}$ \\
\hline Industry & $\begin{array}{l}\text { Co-opetition: UNICEF itself represents } 40 \% \text { of the global volume, Gavi is } 50 \% \text { of this procure- } \\
\text { ment \& increased supply base from } 5 \text { manufacturers to } 13(2010) \text { with } 7 \text { in developing coun- } \\
\text { tries. Gavi countries represent } 60 \% \text { of the world birth cohort. }\end{array}$ \\
\hline Growth & $\begin{array}{l}\text { Phase 1- (1999-2005) } \\
\text { Protoboard creates GAVI, GAVI Board meets, Vaccine Fund is created, GAVI Alliance Secre- } \\
\text { tariat formed and funded by Bill \& Melinda Gates Foundation who make the preliminary } \\
\text { grant. } \\
\text { GAVI Alliance and Vaccine Fund are officially “launched" Vaccine Fund create Executive } \\
\text { Committee Gates Foundation, UK and other private foundations contribute. } \\
\text { Vaccine Fund hires management staff Denmark, the Netherlands, Norway, Sweden, the US } \\
\text { make initial contributions to Injection Safety (INS) window is introduced. } \\
\text { Decision made to merge GAVI Alliance Secretariat and Vaccine Fund management. New } \\
\text { GAVI Executive Secretary appointed, effective 2005. } \\
\text { Phase 2- (2006-2010) } \\
\text { Gavi added two new vaccines to its portfolio: pneumococcal and rotavirus; } \\
\text { a new vaccine investment strategy and a platform for accelerating the introduction of new } \\
\text { vaccines in developing countries (Accelerated Vaccine } \\
\text { Introduction) were developed; } \\
\text { it became increasingly clear that parallel investment was needed in health systems and delivery } \\
\text { systems, with the Vaccine Alliance extending its support to health system strengthening and civil } \\
\text { society organizations; several fundamental policies and programmes were developed and re- } \\
\text { viewed, including co- financing, gender, and eligibility as well as } \\
\text { innovative financing mechanisms such as the Innovative Finance Facility for Immunization (IF- } \\
\text { FIm) in } 2005 \text { and the Advance Market Commitment (AMC). } \\
\text { Phase 3- (2011-2015) } \\
\text { The vaccine goal: accelerate the uptake and use of underused and new vaccines; } \\
\text { The health systems goal: contribute to strengthening the capacity of integrated health } \\
\text { systems to deliver immunization; } \\
\text { The financing goal: increase the predictability of global financing and improve the sustainabil- } \\
\text { ity of national financing for immunization; } \\
\text { The market-shaping goal: shape vaccine markets. } \\
\text { The vaccine goal: accelerate equitable uptake and coverage of vaccines; } \\
\text { The systems' goal: increase the effectiveness and efficiency of immunization delivery as an } \\
\text { integrated part of strengthened health systems; } \\
\text { The sustainability goal: improve the sustainability of national immunization programmes; } \\
\text { The market-shaping goal: shape markets for vaccines and other immunization products. }\end{array}$ \\
\hline & International institution based in Switzerland and public charity status in the United States. \\
\hline
\end{tabular}

\section{Motives}

Gavi is an IGO focused on bringing together the public and private sectors with the shared goal of creating equal access to new and underused vaccines for children living in the world's poorest countries. The motives of Gavi change slightly from each 5-year plan (see Table 5). From reaching the 
world's most impoverished children to ensure essential vaccinations, the age base has changed, as has the markets. In 2020 due to the global pandemic - the COVAX, a multilateral approach to procuring vaccines was introduced. COVAX has the support of 190 participating economies and will benefit 92 lower-income countries. The motives slightly changed the current situation to (1) include more vaccines (2) extend the coverage to adults (3) focused more on innovative financing (4) market shaping and systems approach to go beyond vaccines to supply chain with a focus on sustainability. Of course, some events were shaped by the 2014 Ebola and 2020 COVID pandemics. From a theoretical lens, looking at Table 1, the motive of health needs to be added to the purpose (it is more specific than general), and the focus on motives is normative.

Table 5. Gavi Motives during the period of 2000-2025

\begin{tabular}{|c|c|c|c|c|c|}
\hline Pre-formation & $\begin{array}{c}\text { Phase 1- } \\
(2000-2006)\end{array}$ & $\begin{array}{c}\text { Phase 2- } \\
(2007-2010)\end{array}$ & $\begin{array}{c}\text { Phase 3- } \\
\text { (2011- 2015) }\end{array}$ & $\begin{array}{c}\text { Phase 4- } \\
\text { (2016- 2020) }\end{array}$ & $\begin{array}{c}\text { Phase 5- } \\
\text { (2021-2025) }\end{array}$ \\
\hline $\begin{array}{l}\text { To reach some of } \\
\text { the poorest chil- } \\
\text { dren and get then } \\
\text { basic vaccinations } \\
\text { ( } 6 \text { vaccines) }\end{array}$ & $\begin{array}{l}\text { GAVI's vaccine } \\
\text { strategy in Phase } \\
1 \text {, based on the } \\
\text { assumption that } \\
\text { creating and } \\
\text { demonstrating a } \\
\text { market for vac- } \\
\text { cines in develop- } \\
\text { ing countries } \\
\text { would attract } \\
\text { new suppliers, } \\
\text { create competi- } \\
\text { tion, and lower } \\
\text { prices. }\end{array}$ & $\begin{array}{l}\text { Goals } \\
\text { - Strengthen ca- } \\
\text { pacity for health } \\
\text { system } \\
\text { - Accelerate vac- } \\
\text { cines } \\
\text { - Increase predict- } \\
\text { ability and sus- } \\
\text { tainability } \\
\text { - Increase and as- } \\
\text { sess the added } \\
\text { value of Gavi } \\
\text { (8 vaccines) } \\
\text { Innovative funding } \\
\text { mechanisms } \\
\text { through AMC and } \\
\text { IFFIm. }\end{array}$ & $\begin{array}{l}\text { Goals } \\
\text { - vaccine goal } \\
\text { - health systems } \\
\text { goal } \\
\text { - financing goal } \\
\text { - market-shaping } \\
\text { goal } \\
\text { Additional focus } \\
\text { on Monitoring \& } \\
\text { Evaluation; Advo- } \\
\text { cacy, Communi- } \\
\text { cation \&Public } \\
\text { policy and policy } \\
\text { Stockpiling for fu- } \\
\text { ture pandemics } \\
\text { or outbreaks. }\end{array}$ & $\begin{array}{l}\text { Goals } \\
\text { - vaccine goal } \\
\text { - systems' goal } \\
\text { - sustainability } \\
\text { goal } \\
\text { - market-shap- } \\
\text { ing goals } \\
\\
\text { (During Ebola } \\
\text { epidemic) }\end{array}$ & $\begin{array}{l}\text { Goals } \\
\text { - To introduce } \\
\text { and scaleup } \\
\text { vaccines } \\
\text { - strengthen } \\
\text { health systems } \\
\text { to increase eq- } \\
\text { uity in immun- } \\
\text { ization } \\
\text { - Improve sus- } \\
\text { tainability of } \\
\text { immunization } \\
\text { programs } \\
\text { - Ensure healthy } \\
\text { markets for } \\
\text { vaccines and } \\
\text { related prod- } \\
\text { ucts }\end{array}$ \\
\hline
\end{tabular}

Source: own study.

Through seeking funds strategically (think of the Sukuk) or COVAX, working on diversifying vaccine manufacturing, Gavi has been strategic in seeking and deploying funds. This is because Gavi gives advances funds to research and development by guaranteeing procurement. This has worked well in creating a global factory (see Figure 1).At the time of Gavi's formation, most of the aid, research, and manufacturing capabilities were based in developed countries, and the impact countries were in developing countries. In 2001, Gavi bought vaccines through UNICEF from five manufacturers, but by 2016, it was purchasing vaccines from 15 manufacturers -8 of which were based in Asia, Latin America, and Africa. By accumulating orders, R\&D to find more cost-effective ways for delivery and manufacture, Gavi was able to bridge the price gap that often contributed to vaccine inequality. Gavi captured "sticky capabilities" through public-private partnerships - for example, WHO would pre-qualify vaccines, World Bank used its financial expertise to help design, implement and manage innovative financing, UNICEF worked on the ground in delivering vaccines, and CSOs in local communities helped in ensuring the vaccines were delivered correctly. 


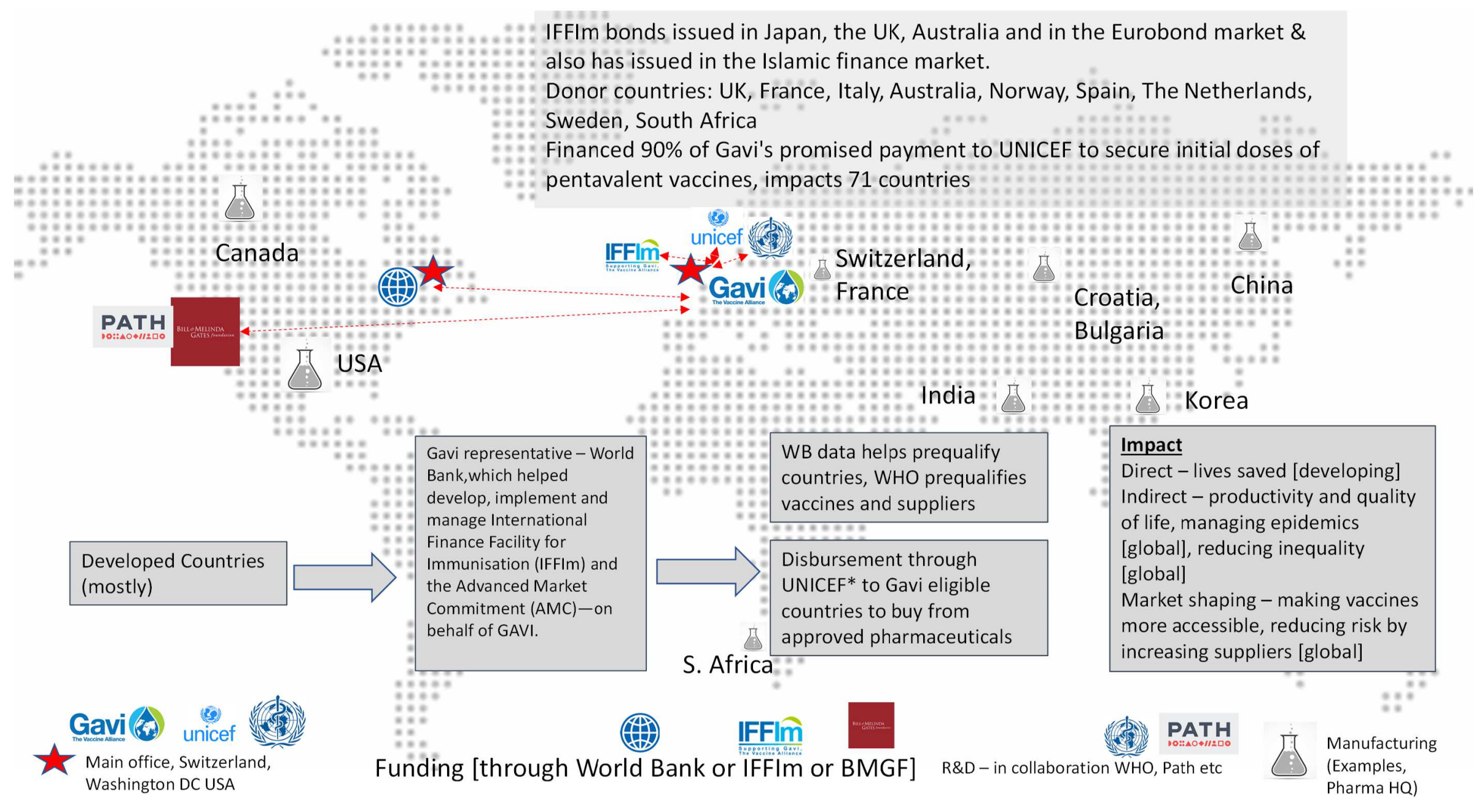

Figure 1. Gavi, the vaccine alliance - An example of networking using the Global Factory concept, 2000-2016 Source: own study 


\section{Networks: Sources of Legitimacy and Soft Power}

The networks of Gavi are other IGOs, Governments, and private sectors (see Table 6). UNICEF housed Gavi's early initiative in Geneva until it became an independent foundation in 2008. It is clear that even in the beginning, the vision for Gavi was global with a partnership model. The Board is comprised of 28 seats (nine seats for unaffiliated members, five seats for donor countries, five for developing countries, one seat for research and technical health center, one seat for a vaccine manufacturers from a developed country, one seat from a vaccine manufacturer from a developing country, one seat for a Civil Service Organization (CSO), one seat for the Gavi CEO, four founding members (Bill \& Melinda Gates Foundation, UNICEF, World Bank, and WHO). This ensures the partnership or 'alliance' brought together key stakeholders needed to reach the vaccine agenda.

The six largest donors of Gavi contribute more than two-thirds of these resources. They are the United Kingdom, Bill \& Melinda Gates Foundation (significant player in vaccine market), Norway, United States, France, and Italy. Gavi tapped into existing pools of vast experience using market-shaping strategies and industry consolidation of sorts. A network effect is evident in smaller firms in previous literature (Freeman et al., 2006) and applies to IGOs, which can mobilize vast sums of money and tap into existing resources held by other players in the market. Further, we see how the network effect moves from Gavi through local health ministries and CSOs working with UNICEF, WHO, and World Bank. Unlike MNEs, here, the HQ-subsidiary impact is not relevant.

Table 6. Gavi Networks: examples for the 2000-2020 period

\begin{tabular}{|c|c|c|c|c|}
\hline Pre-formation & Phase 1- (2000-2006) & Phase 2- (2007-2010), & Phase 3- (2011-2015) & Phase 4- (2016-2020 \\
\hline $\begin{array}{l}\text { Announced at a } \\
2 \text { nd Vaccine } \\
\text { Summit con- } \\
\text { vened by World } \\
\text { Bank in Italy as } \\
\text { Informal part- } \\
\text { nership of UN } \\
\text { agencies, bilat- } \\
\text { eral aid organi- } \\
\text { zation, vaccine } \\
\text { industry. } \\
\text { Another Signifi- } \\
\text { cant Advocate is } \\
\text { the Bill \& } \\
\text { Melinda Gates } \\
\text { Foundation. }\end{array}$ & $\begin{array}{l}\text { Set up in Geneva in } \\
1999 \text { hosted by } \\
\text { UNICEF. UNICEF is } \\
\text { one of the largest } \\
\text { procurers of vaccines. } \\
\text { Officially launched in } \\
\text { WEF } 2000 . \\
5 \text { manufactures of } \\
\text { vaccines (developed } \\
\text { countries). } \\
\text { AMC idea presented } \\
\text { to G8. G7 looks at } \\
\text { feasibility with WB. } \\
\text { DFIF (UK) seeds the } \\
\text { idea for IFFIm, which } \\
\text { is registerd as a char- } \\
\text { ity in UK and formal } \\
\text { collaboration in } 2004 .\end{array}$ & $\begin{array}{l}* 2008 \text { became inde- } \\
\text { pendent Swiss Founda- } \\
\text { tion under Swiss Na- } \\
\text { tional Lawa and two of- } \\
\text { fices - Geneva and } \\
\text { Washington. } \\
\text { *WB HQ is Washington } \\
\text { *WB is the Treasury } \\
\text { Manager for Interna- } \\
\text { tional Finance Facility } \\
\text { for Immunisation (IF- } \\
\text { FIm), provides the fi- } \\
\text { nancial platform for } \\
\text { the Advanced Market } \\
\text { Commitment (AMC). } \\
\text { Further, WB is a devel- } \\
\text { opment partner at the } \\
\text { global and country lev- } \\
\text { els. } \\
\text { AMC launched in } 2007 . \\
\text { IFFIm launched in } \\
2006 .\end{array}$ & $\begin{array}{l}\text { IFFIm diversified and } \\
\text { raise a Sukuk in } 2014- \\
\text { half of Gavi countries } \\
\text { are Muslim. } \\
\text { The UK sponsored the } \\
\text { first Gavi Pledging con- } \\
\text { ference in } 2011 . \\
\text { Germany sponsored } \\
\text { the second Gavi Pledg- } \\
\text { ing Conference in } 2015 .\end{array}$ & $\begin{array}{l}15 \text { vaccines manufac- } \\
\text { turers (2016) - } 8 \text { in } \\
\text { Asia, Africa, and Latin } \\
\text { America } \\
\text { "A new model for sus- } \\
\text { tainable develop- } \\
\text { ment: how Gavi aims } \\
\text { to put itself out of } \\
\text { business" }\end{array}$ \\
\hline
\end{tabular}

Source: own study.

Gavi has tremendous power: In terms of vaccine producing volume, UNICEF is $40 \%$ of the global volume, and Gavi is $50 \%$ of this procurement. Gavi countries represent $60 \%$ of the world's birth cohort. Not only did Gavi redress the imbalance in vaccine manufacturing, but it was also able to bring down costs. An HPV vaccine for cervical cancer, which was available for US dollar 100 in developed countries, was made available through Gavi for US dollar 13. 
Gavi was able to achieve these tremendous results with an accrual of legitimacy (Bianchi \& Arnold, 2004; Bianchi\& Ostale, 2006). Legitimacy, a strategic resource (see Pfeffer, 1981; Suchman, 1995), was accrued by Gavi through key players like people (such as Bill Gates), or organizations (UNICEF, WB, and IFF) and expert knowledge (PATH, WHO, WB), using specialized resources (Pharma and R\&D companies for vaccine manufacturing) to make integration easier across the world, industry-shaping (through innovative financing to change the competitive landscape), and showed dominance (as a significant player in their industries now not to be ignored).

Legitimacy was used as a strategy used to acquire resources where Gavi worked with World Bank using accounting for legitimacy (Covaleski \& Dirsmith, 1991) to enter entered the Sukuk market in 2014. This is significant, as $50 \%$ of Gavi countries are Muslim countries. This is in line with the propositions outlined by Meyer and Rowan (1977).

Knowledge spillovers can occur at both horizontal (competitors) and vertical levels (across the supply chain) and can be intentional or unintentional (Ha \& Giroud, 2015; Hallin \& Lind, 2012). In the case of Gavi, to increase the supply chain resilience and contribute to the SDG agenda, and by its governance structure, there was an intentional focus on competency enhancing competence-creating resources, which can take more than a decade to affect technology (Kappen, 2011).

The concept of soft power from an organizational perspective is also observable as Gavi can influence governments. Gavi strategically based itself in Geneva (near UNICEF and WHO) and Washington DC (near the World Bank). In this case, we see soft power extended by donor countries on recipient countries (via vaccine pledges) or institutions in other countries (Gavi and UNICEF). This suggests soft power is multidimensional. The Aid Transparency Index (2020) scores GAVI at 80.8 in the 'very good' category (11th out of 47 major international development organizations.

Soft power or inverse country-of-origin ( $\mathrm{COO}$ ) can be translated through various channels like people and MNEs (or institutions), brands, and aid (Fan, 2008; White, 2012). In this case study, this is observed through Bill Gates (USA), UNICEF and WHO (Switzerland), World Bank (USA), and Gavi (Switzerland/USA) and their influence on other countries.

As mentioned before, Gavi's global expansion leveraged the networks of its partners. This multistakeholder model is not unusual for IGOs and requires diplomacy to reach its objectives. Often, stakeholders are acquired based on interest and expertise or even persuaded to be 'stakegivers' or 'staketakers' (Hocking, 2006). Gavi diversified risks by spreading the risks across at least three continents, following much of what we know is the internationalization strategy of born global (Oviatt \& McDougall 2005).

\section{Findings and Discussion}

The case above clearly finds an IGO can play a prominent role in the global supply chain using motives like Strategic Asset Seeking FDI, networking for legitimacy, and soft power. Our current IB theories are not sufficient to explain all the reasons for the successful internationalization of these categories of organizations. According to the Global Factory theory, HQ retains the brand and associated functions. In the case of Gavi, care was taken to leverage associated stakeholder brands as it was vital for legitimacy. Gavi has two key offices - Switzerland and New York and these are very strategic. However, partner brands are significant, as seen by the name change - Gavi was first called Gavi, and then renamed Gavi, the Vaccine Alliance in Balakrishnan (2020). Gavi began with a powerful global vision and had access to powerful and legitimate resources, grounding their aspirations.

Further, the game was long-term. The effect of soft power is evident in Gavi, which requires a high level of diplomacy - high technology in a sector often restricted by governments. Gavi works on the health agenda with strong players in the development space, which are other IGOs and through donor countries on the boards of several of these IGOs. This is done without a clear articulation of roles. This process of internationalization is a careful act of diplomacy, and corporate diplomacy theories are not enough to explain the IGO internationalization strategy. We suggest the process of internationalization of IGOs works in three phases (1) creation of a market for impact (2) identifying a market for resources, and (3) managing governance (and hence reputation). This is done through a careful strategy of soft power (see Figure 3 ). 


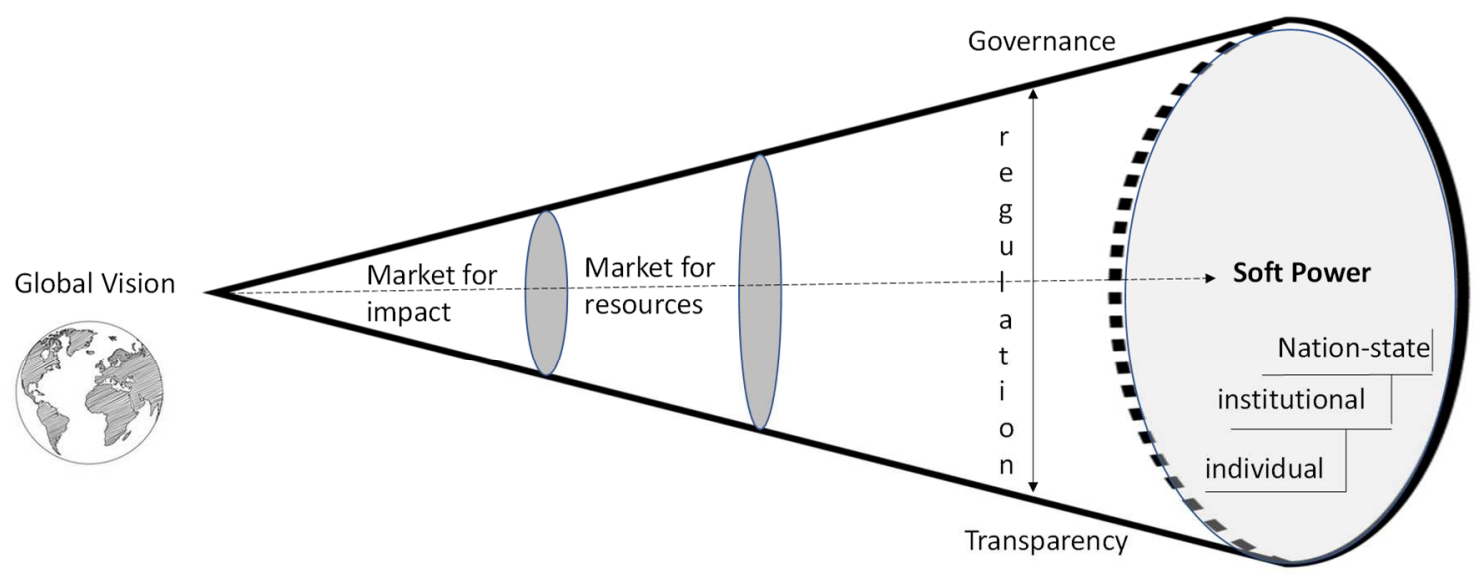

LEGITIMACY

Figure 3. The process of Internationalization of IGOs

Source: own elaboration.

\section{CONCLUSIONS}

This research's objective was to push the boundaries of IB theory and contribute to both policy and academia, which often seem to exist in different spheres (Newman et al., 2016). The paper adds to our understanding of how IGOs internationalize. It highlights new areas of research like that of soft power. The current internationalization models of SMEs and MNEs may not neatly fit in the context of IGOs (which are born global). We reiterate that existing IB theories need to be applied to other state actors like sovereign wealth funds and non-governmental organizations. The above case study, a detailed historical analysis using thick data, is a methodology not often published.

The paper's implications are for policymakers and practitioners in the third sector, including those who invested interest at state-represented foreign direct investment. Future studies can look at how networks are leveraged, spillover occurs from a personal level to an institutional level, and vice-versa combine diplomacy, bargaining, and legitimacy. The limitation of this study is that it is based on a single case. More empirical studies could focus on more institutions and organizations that operate globally, adding to large organizations' sensemaking with huge portfolios and strongly articulated portfolios.

\section{REFERENCES}

Aid Transparency Index (2020). 2020 Aid Transparency Index. Retrieved fromhttps://www.publishwhatyoufund.org/wp-content/uploads/dlm_uploads/2020/06/2020-Aid-Transparency-Index-report.pdf on 1 May 2021.

Alcacer, J.,\& Ingram, P. (2013). Spanning the institutional abyss: The intergovernmental network and the governance of foreign direct investment. American Journal of Sociology, 118, 1055- 1098.

Balakrishnan, M. S. (2020). Business with Purpose: Advancing Social Enterprise. World Scientific.

Beckfield, J. (2003). Inequality in the world polity: The structure of international organization. American Sociological Review, 68(3), 401-424.

Behrendt, S. (2009). Gulf Arab SWFs: Managing wealth in turbulent times and beyond. Carnegie Endowment for International Peace. Carnegie Middle East Center, 16, 1-56. Retrieved from: https://carnegieendowment.org/files/sovereign_wealth_turbulent.pdf

Bianchi, C.C., \& Arnold, S.J. (2004). An institutional perspective on retail internationalization success: Home Depot in Chile. International Review of Retail, Distribution and Consumer Research, 14(2), 149-169.

Bianchi, C.C., \& Ostale, E. (2006). Lessons learned from unsuccessful internationalization attempts: Examples of multinational retailers in Chile. Journal of Business Research, 59(1), 140-147. 
Birkinshaw, J., Brannen, M. Y., \& Tung, R. L. (2011). From a distance and generalizable to up close and grounded: Reclaiming a place for qualitative methods in international business research. Journal of International Business Studies, 42, 573-581. https://doi.org/10.1057/jibs.2011.19

Boehmer, C., Gartzke, E., \& Nordstrom, T. (2004). Do intergovernmental organizations promote peace?. World Politics, 57(1), 1-38.

Bourdieu, P. (1990). The logic of practice. Stanford University Press.

Buckley,P.J.(2004).TheroleofChinaintheglobalstrategyofmultinationalenterprises.JournalofChineseEconomicandBusinessStudies,2(1),1-25.

Buckley,P.J.

(2009a).Theimpactoftheglobalfactoryoneconomicdevelopment.JournalofWorldBusiness, $44(2), 131143$.

Buckley,P.J. (2009b).TheriseoftheJapanesemultinationalenterprise:thenandnow.AsiaPacific Business Review,15(3),309-321.

Corbin, J., \& Strauss, A. (2014). Basics of qualitative research: Techniques and procedures for developing grounded theory. Sage Publications.

Covaleski, M.A., \& Dirsmith, M.W. (1991). The management of legitimacy and politics in public sector administration. Journal of Accounting and Public Policy, 10(2), 135-156.

Deephouse, D.L., \& Carter, S.M. (2005). An examination of differences between organizational legitimacy and organizational reputation. Journal of Management Studies, 42(2), 329-360.

Doz, Y. (2011). Qualitative research for international business. Journal of International Business Studies, 42(5), 582-590.

Dunning, J.H., (1988). Explaining International Production. Unwin Hyman.

Dunning, J.H., (1993). The Globalization of Business. Routledge.

Dunning, J.H. (2001). The eclectic (OLI) paradigm of international production: past, present, and future. International Journal of the Economics of Business, 8(2), 173-190.

Dunning, J.H., \& Lundan, S.M. (2008). Multinational enterprises and the global economy. 2nd ed. Edward Elgar Publishing Limited.

Eisenhardt, K.M., \& Graebner, M.E. (2007). Theory building from cases: Opportunities and challenges. The Academy of Management Journal, 50(1), 25-32.

European Parliament (2020). Understanding the financing of intergovernmental organizations. A snapshot of the budgets of the UN, NATO and WTO. Retrieved from https://www.europarl.europa.eu/RegData/etudes/BRIE/2020/652084/EPRS_BRI(2020)652084_EN.pdf on 1 June 2021.

Fan, Y. (2008). Soft power: Power of attraction or confusion. Place Branding and Public Diplomacy, 4(2), $147-58$.

Freeman, S., Edwards, R., \& Schroder, B. (2006). How smaller born-global firms use networks and alliances to overcome constraints to rapid internationalization. Journal of International Marketing, 14(3), 33-63.

Gallarotti, G. M. (1989). Legitimacy as a capital asset of the state. Public Choice, 63(1), 43-61.

Gavi. (2019). Vaccine Goal Indicators. Retrieved from: https://www.gavi.org/programmes-impact/our-impact/measuring-our-performance/2016-2020-indicatorsAccessed 12 May, 2020.

Gereffi, G., \& Korzeniewicz, M. (Eds.). (1994). Commodity chains and global capitalism. ABC-CLIO, No. 149.

Goldstone, J.A. (1991). Revolution and rebellion in the early modern world. University of California Press.

Grant, R.M. (2003). Strategic planning in a turbulent environment: Evidence from the oil majors. Strategic Management Journal 24(6), 491-517.

Ha, Y.J., \& Giroud, A. (2015). Competence-creating subsidiaries and FDI technology spillovers. International Business Review, 24(4), 605-614.

Hallin, C., \& Lind, C.H. (2012). Revisiting the external impact of MNEs: An empirical study of the mechanisms behind knowledge spillovers from MNE subsidiaries. International Business Review, 21(2), 167-179.

Haynes, J., Hough, P., Malik, S., \& Pettiford, L. (2017). World politics: International relations and globalisation in the 21st century. Sage.

Hocking, B. (2006). Multi-stakeholder diplomacy: forms, functions, and frustrations. In J. Kurbalija \& V. Katrandjiev (Eds), Multi-stakeholder diplomacy: Challenges and opportunities(pp. 13-29). DiploFoundation. 
Hoon, C. (2013). Meta-synthesis of qualitative case studies: An approach to theory building. Organizational Research Methods, 16(4), 522-556.

Hough, M., Jackson, J., Bradford, B., Myhill, A., \& Quinton, P. (2010). Procedural justice, trust, and institutional legitimacy. Policing: a Journal of Policy and Practice, 4(3), 203-210.

Ingram, P., Robinson, J., \& Busch, M. L. (2005). The intergovernmental network of world trade: IGO connectedness, governance, and embeddedness. American Journal of Sociology, 111(3), 824-858.

IMF (2018). Annual Report. Retrieved fromhttps://www.imf.org/external/pubs/ft/ar/2018/eng/assets/pdf/imfannual-report-2018.pdf on 1 May 2021.

Jackson, J. H. (2006). Sovereignty, the WTO, and changing fundamentals of international law. Cambridge University Press.

Jandhyala, S., \& Phene, A. (2015). The role of intergovernmental organizations in cross-border knowledge transfer and innovation. Administrative Science Quarterly, 60(4), 712-743.

Kappen, P. (2011). Competence-creating overlaps and subsidiary technological evolution in the multinational corporation. Research Policy, 40(5), 673-686.

Koremenos, B., Lipson, C., \& Snidal, D. (2001). The rational design of international institutions. International Organization, 55(4), 761-799.

Lee,T.(2010). Theriseofinternationalnon-governmentalorganizations:Atop-downorbottom-upexplanation?.Voluntas: International Journal of Voluntary and Non-profitOrganizations,21(3),393-416.

Lorrain, F., \& White, H. C. (1971). Structural equivalence of individuals in social networks. Journal of Mathematical Sociology, 1(1), 49-80.

Mearsheimer, J. J. (2011). The false promise of international institutions. In J.J. Mearsheimer (Ed.), Security Studies(pp. 153-161). Routledge.

Meyer, K.E. (2015). What is "strategic asset seeking FDI"?. Multinational Business Review, 23(1), 57-66.

Meyer, J. W., \& Rowan, B. (1977). Institutionalized organizations: Formal structure as myth and ceremony. American Journal of Sociology, 83(2), 340-363.

Meyer, K. E., Wright, M.\& Pruthi, S. (2009). Managing knowledge in foreign entry strategies: A resource-based analysis.Strategic Management Journal, 30(5), 557-574.

Milner, H. V. (1999). The political economy of international trade. Annual Review of Political Science, 2(1), 91-114.

Moore, E., Brandl, K., \& Dau, L. A. (2019). Institutional schisms in Argentina: The impact of intergovernmental organizations on country institutional environments. In: International Business in a VUCA World: The Changing Role of States and Firms (pp.89-102). Emerald Publishing Limited.

Narula, R. (2006). Globalization, new ecologies, new zoologies, and the purported death of the eclectic paradigm. Asia Pacific Journal of Management, 23(2), 143-151.

Narula, R., \& Dunning, J.H. (2000). Industrial development, globalization and multinational enterprises: new realities for developing countries. Oxford Development Studies, 28(2), 141-167.

Narula, R. \& Zanfei, A. (2004). Globalization of innovation: The role of multinational enterprises -Oxford Handbook of Innovation. Oxford University Press.

Newman, J., Cherney, A. \& Head, B.W., (2016). Do policymakers use academic research? Reexamining the "two communities" theory of research utilization. Public Administration Review, 76(1), pp.24-32.

Nye, Jr. J.S. (1990). Soft power. Foreign Policy, 80, 153-171.

Nye Jr, J. S. (2008). Public diplomacy and soft power. Annals of the American Academy of Political and Social Science, 616(1), 94-109.

Nye Jr, J. S. (2009). Soft Power: The Means To Success In World Politics. Hachette UK.

Oviatt, B.M., \& McDougall, P.P. (2005). Defining international entrepreneurship and modeling the speed of internationalization. Entrepreneurship Theory and Practice, 29(5), 537-553.

Pananond, P. (2015). Motives for foreign direct investment: a view from emerging market multinationals. The Multinational Business Review, 23(1), 77-86.

Pfeffer, J. (1981). Management as symbolic action: the creation and maintenance of organizational paradigm. Research in Organizational Behavior, 3, 1-52. 
Shenkar, O. (2004). One more time: International business in a global economy. Journal of International Business Studies, 35(2), 161-171.

Suchman, M.C. (1995). Managing legitimacy: Strategic and institutional approaches. Academy of Management Review, 20(3), 571-610.

Suddaby, R. (2010). Challenges for institutional theory. Journal of Management Inquiry, 19(1), 14-20.

Stephens Balakrishnan, M. (2016). Gavi: The vaccine alliance: Saving lives one vaccine at a time, In M.S. Balakrishnan \& V. Lindsay (Eds.), Actions and Insights: Middle East North Africa (pp. 136-192). Emerald Publishing.

Stephens Balakrishnan, M.\& Moonesar, I.A. (2011). Advanced Technology Investment Company(ATIC): a destination, global champion. Emerald Emerging Markets Case Studies, 1(4), 1-20.

Stephens Balakrishnan, M. \& Moonesar, I.A. (2017). UAE Sovereign Wealth Funds as Enablers of the Global Factory. November, Issue 45, Mohammed Bin Rashid School of Government.

Teegen, H., Doh, J.P., \& Vachani, S. (2004). The importance of non-governmental organizations (NGOs) in global governance and value creation: An international business research agenda. Journal of International Business Studies, 35(6), 463-483.

Turchin, P., \& Nefedov, S.A. (2009). Secular cycles. Princeton University Press.

UIA (2018). Union of International Associations. Retrieved from https://uia.org/on 21 January 2021.

Vabulas, F., \& Snidal, D. (2013). Organization without delegation: Informal intergovernmental organizations (IIGOs) and the spectrum of intergovernmental arrangements. Review of International Organizations, 8(2), 193-220.

Weststeijn, A. (2014). The VOC as a company-state: Debating seventeenth-century Dutch colonial expansion. Itinerario, 38(1), 13-34.

White, C. L. (2012). Brands and national image: An exploration of inverse country-of-origin effect. Place Branding and Public Diplomacy, 8(2), 110-118.

Yin, R. K. (1994). Case study research: design and methods. Thousand Oaks, CA.

Zucchella, A., Palamara, G., \& Denicolai, S. (2007). The drivers of the early internationalization of the firm. Journal of World Business, 42(3), 268-280. 


\section{Authors}

The contribution share of authors is equal and amounted to $50 \%$ for each of them. MS - conceptualization, literature writing, case date collection, MS \& IAM - methodology, results, discussion, and conclusion.

\section{Melodena Stephens}

Professor of Innovation Management at Mohammed Bin Rashid School of Government (UAE). Ph.D.in Management Studies (2004, Bharati Vidyapeeth University, India). Her research interests include branding, country soft power, social impact, and scaling.

Correspondence to: Prof. Dr Melodena Stephens, Mohammed Bin Rashid School of Government, Convention Tower (Level 7), P.O. Box 72229, Dubai, United Arab Emirates, e-mail: melodena.stephensb@mbrsg.ac.ae

ORCID (1) http://orcid.org/0000-0001-7933-2750

\section{Immanuel Azaad Moonesar}

Associate Professor of Health Administration and Policy at Mohammed Bin Rashid School of Government (UAE).Ph.D.in Health Services-Leadership (Walden University, USA). His research interests include international business policy, health policy, public policy, social policy, policy analyst, maternal and child health care policy. Correspondence to: Dr Immanuel Azaad Moonesar, Mohammed Bin Rashid School of Government, Convention Tower (Level 7), P.O. Box 72229, Dubai, United Arab Emirates, e-mail: immanuel.moonesar@mbrsg.ac.ae ORCID (ib http://orcid.org/0000-0003-4027-3508

\section{Acknowledgements and Financial Disclosure}

The authors would like to express their gratitude to the UAE National Research Foundation and Mohammed Bin Rashid School of Government, Dubai, United Arab Emirates. The authors would like to thank the anonymous referees for their valuable comments, which allowed to increase the value of this article.

\section{Conflict of Interest}

The authors declare that the research was conducted in the absence of any commercial or financial relationships that could be construed as a potential conflict of interest.

\section{Copyright and License}

This article is published under the terms of the Creative Commons Attribution - NoDerivs (CC BY-ND 4.0) License http://creativecommons.org/licenses/by-nd/4.0/ 
